\title{
Environmental Performance, Environmental Costs and Financial Performance
}

\author{
Mia Angelina Setiawan ${ }^{1, *}$, Fiola Finomia Honesty ${ }^{2}$ \\ ${ }^{1,2}$ Universitas Negeri Padang, Padang, Indonesia \\ *Corresponding Author. Email: miaangelinasetiawan@gmail.com
}

\begin{abstract}
The purpose of this research was to determine the effect of environmental performance and environmental costs on financial performance. This research uses a quantitative method. Purposive sampling method is used in sample selection in which the companies studied are mining and manufacturing companies in Indonesia which are listed on the Stock Exchange. This research uses ratio analysis to measure financial performance and measure environmental performance sorted by PROPER rating, to measure environmental cost used data obtained by looking for a percentage of the environmental cost and then statistical methods to test the hypothesis. The results of this research indicate that only the environmental costs has an effect on the financial performance of mining and manufacturing companies with a significant level 0.047. It means that the disclosure of environmental costs carried out by mining and manufacturing companies in Indonesia for the 2014-2018 period has an impact on financial performance, and the company's concern, both in terms of costs for environmental prevention, costs for environmental detection, costs for internal failure and costs for external environmental failure can minimize the risk of environmental pollution.
\end{abstract}

Keywords: Financial performance, environmental performance, and environmental cost.

\section{INTRODUCTION}

Environmental problems have now become the world's public attention which is very important to discuss. This raises various demands for companies to pay more attention to responsibility and to be responsible for environmental conditions and the surrounding community.

Various environmental problems in Indonesia still occur and must be followed up. The result of environmental pollution is getting worse, which is the impact of environmental management inconsistencies with established standards.

Case environmental pollution that occurs in the waters of GAG Island, where the pollution is caused by The nickel mining waste of PT GAG, a subsidiary of PT Antam Tbk, has made GAG Island Waters become brown.

Environmental pollution that occurs due to mining activities cement in Tuban is thought to be the main cause of death in the area, this death is due to high air pollution around the cement mining area. Apart from air pollution, water pollution has also been felt by the community, such as changes in the condition of residents wells that have became salty.

The results of investigations released by Greenpeace Indonesia regarding coal mining activities by PT Indominco Mandiri, which is a subsidiary of PT Indo Tambangraya Megah Tbk, destroying the landscape and disturbing the quality of groundwater. Which land originally a forest and food land into abandoned and ex- mining lakes arid land, so that people complain about water scarcity.

Very important in a company to pay attention to environmental problems, especially mining companies and manufacturing companies whose industrial activities explore natural resources and have a negative impact on the environment.

Research conducted by [1] The effect of environmental performance, environmental costs, on financial performance shows that environmental performance have not the effect on financial performance and environmental costs have significant negative effect on financial performance. According to the results of research conducted by [2] examining the relationship between environmental costs and environmental performance on financial performance, it shows that the results of environmental costs have no effect on financial performance and environmental performance has a significant effect on financial performance.

Based on the explanation above, it can be seen that there is a link between environmental performance and environmental costs on financial performance. For this reason, researchers are interested in conducting further research using samples of mining companies and manufacturing companies listed on the Indonesia Stock Exchange (IDX) because they are companies that have a direct impact on the environment. 


\section{LITERATURE REVIEW}

\subsection{Research Theory}

The research uses stakeholder theory and legitimacy theory. Based on stakeholder theory, the company is not just operating for its own benefit, but must also pay attention to the interests of stakeholders [3]. Because the support from stakeholders also affects the company's survival. Stakeholder theory arises because of circumstances (law) that prioritize the interests of shareholders. Disclosure of environmental information is a key process in accounting for company performance to stakeholders through financial reporting. Companies must have a responsibility as a form of concern for the adverse environmental impacts of their industrial activities. This responsibility can be done by disclosing environmental costs in the financial statements to inform stakeholders that the company has carried out its environmental responsibility. According to [4] The disclosure of environmental costs by the company will provide a positive signal for stakeholders where the company has performed well in the environment and the company hopes that this can have a positive impact on financial performance.

Legitimacy theory states that companies or organizations must ascertain whether they have operated within the norms upheld by society and ensure that their activities can be accepted by outsiders (legitimized). According to [3], explaining that companies conduct its business within the limits determined by social values, norms and reactions for this limitation encourages the importance of paying attention to the environment. In an effort to gain legitimacy, companies carry out social and environmental activities that have accounting implications for reporting and disclosure in the company's annual report through published social and environmental reporting. Companies use their annual reports to describe their environmental responsibility, so that the community accepts the company. To maintain legitimacy, the company organization must communicate its environmental activities by making environmental disclosures. It is expected that environmental disclosure will be able to restore, increase and maintain legitimacy that has been received by the company. Therefore, in order for companies to continue to gain legitimacy from the community, companies with good environmental performance should allocate environmental costs.

\subsection{Hypothesis Development}

Environmental performance describes how the company's performance in participating in creating a good environment (green) [5]. Companies are seen as organizations that should obey the rules of society to ensure social responsibility and so that they can continue to exist. In Indonesia, almost all research on environmental performance is measured by adherence sorted by ranking. The ranking is given by the Ministry
Table 1. Descriptive statistics

\begin{tabular}{lc|r|r|r|r}
\hline & N & \multicolumn{1}{c}{$\begin{array}{c}\text { Mini } \\
\text { mum }\end{array}$} & $\begin{array}{c}\text { Maxi } \\
\text { mum }\end{array}$ & \multicolumn{1}{c}{ Mean } & $\begin{array}{c}\text { Std. } \\
\text { Devi-ation }\end{array}$ \\
\hline EP & 145 & 2.00 & 5.00 & 3.19 & 0.680 \\
\hline EC & 145 & 0.07 & 0.64 & 0.39 & 0.151 \\
\hline ROA & 145 & -0.10 & 0.92 & 0.11 & 0.136 \\
\hline $\begin{array}{l}\text { Valid N } \\
\text { (listwise) }\end{array}$ & 145 & & & & \\
\hline
\end{tabular}

of Environment through a program called PROPER. The assessment of PROPER is based on whether the company is compliant or not in meeting the criteria stipulated by laws and regulations and the implementation of various activities related to management activities (beyond compliance).

Research conducted by [6] proved that PROPER is used as a measure of environmental performance the company has an effect on the company's financial performance, this shows that it is getting better Investors will respond positively to environmental performance through fluctuations in the company's stock price can improve the company's financial performance. Environmental performance has a positive and significant effect on financial performance because companies with good environmental performance will get a good response both from stakeholders and have an impact on increasing the company's revenue in the long run [7].

H1: Environmental performance has a significant effect on financial performance

Environmental costs are costs that arise internally and externally company and all costs incurred in connection with or damage environmental protection. These costs such as prevention costs, discharge, planning, repair of damage that occurred in the company. According to [8] the environmental cost is all costs associated with Prevention activity, Detection activity, Internal Failure activity, and External Failures activity. At GRI G4 in the category of environmental aspects: other (G4-EN31) states that companies disclose total expenditure and investment in environmental protection by type. Expenditures for environmental protection based on; (1) costs for waste disposal, emission treatment and remediation (2) environmental management and prevention costs.

Environmental costs are a systematic cost accounting approach and not only focus on environmental protection cost accounting, but also consider environmental costs for materials and energy [1]. Environmental costs are costs incurred by the company concerned Environmental improvement programs due to environmental pollution are carried out by the company on purpose or accidentally. The costs allocated to the natural environment are investment for the company, the company will get social and economic 
benefits in the long run. The application of the environmental cost budget will have an impact on the products produced and marketed. One of them is a positive image to consumers who want to buy products of the highest quality, environmentally friendly and affordable. This will have an impact on increased profitability in an industry [9]. Environmental costs have a positive effect against competitive advantage because the environmental costs incurred by the company can afford increase the company's reputation which has a positive effect on financial performance.

$\mathrm{H}$ 2: Environmental Costs have a significant effect on Financial Performance

\section{RESEARCH METHOD}

This research aims to examine the effect of environmental performance and environmental costs on financial performance. This research uses quantitative methods as an approach to analyzing research problems. The population in this research are mining and manufacturing companies listed on the Indonesia Stock Exchange on the official website www.idx.co.id during the 2014-2018 period. The sample in this research were 29 mining and manufacturing companies listed on the Indonesia Stock Exchange (BEI). The dependent variable in this research is financial performance as measured by using return on assets as a proxy. Ratings are used to measure environmental performance. The rating is given by the government through the Ministry of Environment with the "PROPER" program. The environmental cost measurements are as follows: Environmental costs (detection costs, prevention costs, external failure costs and internal failure costs) divided with the total costs incurred for the environment.

\section{DISCUSSION}

This research examines the effect of environmental performance and environmental costs on financial performance. Environmental performance is measured based on ranking order, the rating is given by the government through the Ministry of Environment with a program called PROPER (Program for Assessing Company Performance in Environmental Management). Environmental cost measurement is as follows: Environmental cost (detection costs, prevention costs, external failure costs and internal failure costs) divided with the total costs incurred for the environment. Meanwhile, financial performance is measured using a proxy ROA.

The companies analyzed in this study are mining and manufacturing companies listed on the Indonesia Stock Exchange. The total number of mining and manufacturing companies listed on the Indonesia Stock Exchange is 234 companies, but those that meet the criteria to be a sample are 29 companies in the 20142018 period with a total sample data that can be processed in this study as many as 145 companies.

Table 1 above explains that the dependent variable on financial performance uses the ROA proxy. Based on the table above, the minimum value of ROA is -0.10 and the maximum value is 0.92 , while the average value is 0.11 and the standard deviation value is 0.136 . Judging from the ROA value, $50 \%$ of the sample above have ROA below the average, meaning that most companies have low return on assets.

Environmental performance which is the independent variable has a minimum value of 2 and a maximum value of 5 , the average value is 3.19 which means the company has been completed compliance with environmental care, but the implementation has not been as expected, and seen from the average value it shows that several companies have carried out environmental maintenance and reached levels above the average.

While environmental costs have a maximum value of 0.64 and a minimum value of 0.07 or an average value of 0.39 . It can be seen from the average value below $50 \%$, this means that there are still many sample companies that do not disclose their environmental costs or the low costs incurred for the environment in their annual reports. This can happen because companies still think that disclosure of environmental costs is not necessary (voluntary disclosure).

Based on the regression testing listed in Table 2 above, the equation can be obtained from multiple regression analysis:

$$
\mathrm{ROA}=0.126+0.014 \mathrm{EP}-0.159 \mathrm{EC}
$$

Table 2 above also shows the value of the environmental performance regression coefficient of 0.014 with a significant value of 0.420 . This shows that environmental performance has no significant effect on financial performance. Regression coefficient value for environmental cost has a value of -0.159 with a

Table 2 Multiple Regression Model Test Results

\begin{tabular}{lc|c|c|c|} 
& \multicolumn{3}{c}{ Coefficients $^{\mathrm{a}}$} \\
& \multicolumn{2}{c}{$\begin{array}{c}\text { Unstandardized } \\
\text { Coefficients }\end{array}$} & $\begin{array}{c}\text { Standardized } \\
\text { Coefficients }\end{array}$ & \\
Model & B & Std. Error & Beta & \multicolumn{1}{c}{ t } \\
\hline 1 (Constant) & .126 & .056 & & 2.270 \\
\hline EP & .014 & .018 & .071 & .809 \\
\hline EC & -.159 & .079 & -.175 & -2.005 \\
\hline
\end{tabular}

a. Dependent Variable: ROA

significant level of 0.047 , So it can be concluded that 
environmental costs have a negative and significant effect on financial performance.

From the results of the above processing, it can be concluded that, environmental performance does not affect the financial performance of mining and manufacturing companies.

While the environmental cost with a significance level of 0.047 means that the disclosure of environmental costs made by the company affects the financial performance of mining and manufacturing companies in Indonesia.

This means that the environmental costs carried out by mining and manufacturing companies in Indonesia for the 2014-2018 period has an impact on the financial performance of the company, and the company's concern, both in terms of detection costs, prevention costs, external failure costs and internal failure costs, can minimize the risk of environmental pollution.

\section{CONCLUSIONS}

This research aims to examine the effect of environmental performance and environmental disclosure on the company's financial performance. This research uses quantitative methods. The sample selection method is purposive sampling method in which the companies studied are mining and manufacturing companies listed on the Indonesia Stock Exchange for the period 2014-2018. Research that uses ratio analysis to measure financial performance and measure environmental performance ranked by PROPER, to measure disclosure of environmental costs by looking for a percentage of the environmental cost. (detection costs, prevention costs, external failure costs and internal failure costs) for the total environmental cost, and then the statistical method for the hypothesis. The results showed that only the disclosure of environmental costs has an effect on the financial performance of mining and manufacturing companies with a significance level of 0.047 . This means that the disclosure of environmental costs carried out by mining and manufacturing companies in Indonesia for the 20142018 period has an impact on the company's financial performance, and the company's concern, both from detection costs, prevention costs, external failure costs and internal failure costs. Can be seen from the risk of environmental pollution.

\section{REFERENCES}

[1] A. Meiyana and M. N. AIsyah, "Pengaruh Kinerja Lingkungan Terhadap Kinerja Keuangan Dengan Corporate Responsibility Sebagai Variabel Intervening Pada Perusahaan Manufaktur Yang
Terdaftar Terdaftar Di Bursa Efek Indonesia Tahun 2015 - 2017," J. NOMINAL, vol. 8, no. 1, 2019.

[2] I. F. Siregar, R. Rasyad, and Zaharman, "Pengaruh Implikasi Biaya lingkungan dan Kinerja Lingkungan Terhadap Kinerja Keuangan Perusahaan Pertambangan Umum Kategori PROPER," J. Ekon. dan Bisnis Dharma Andalas, vol. 21, no. 2, pp. 198-209, 2019.

[3] I. Ghozali and A. Chairiri, Teori Akuntansi. Badan Penerbit UNDIP, 2007

[4] A. P. Sawitri, "Analisis Pengaruh Pengungkapan Akuntansi Lingkungan dan Kinerja Lingkungan terhadap Nilai Perusahaan,” pp. 177-187, 2017.

[5] R. Andayani, "Hubungan Antara Iso 14001, Environmental performance dan Environmental disclosure Terhadap Economic Performance," $J$. Akunt. dan Sist. Teknol. Inf., vol. 11, no. 2, pp. 186-193, 2015.

[6] A. Fitriani, "Pengaruh Kinerja Lingkungan dan Biaya Lingkungan terhadap Kinerja Keuangan pada BUMN," J. Ilmu Manaj., vol. 1, no. 1, pp 137-148, 2013.

[7] T. Djuitaningsih and E. E. Ristiawati, "Pengaruh Kinerja Lingkungan Dan Kepemilikan Asing Terhadap Kinerja Finansial Perusahaan," J. Akunt Univ. Jember, vol. 9, no. 2, p. 31, 2015, doi: 10.19184/jauj.v9i2.1238.

[8] D. R. Hansen and M. . Mowen, Management Accounting, 8th ed. Thomson South Western, 2009.

[9] F. A. Rohelmy, Z. ZA, and H. R. R, "Efektivitas Penerapan Biaya Lingkungan Dalam Upaya Meminimalkan Dampak Lingkungan," J. Adm. Bisnis, vol. 2, no. 2, pp. 1-10, 2015. 